\title{
Chapter
}

\section{Biological control of invasive pests in India}

\author{
Sonu Kumari*, Balbir Singh, \\ Soniya Dhanda and Neeru Dumra
}

Department of Entomology, CCSHAU, Hisar 125004, Haryana, India

\begin{abstract}
Invasive species are one of the major and most rapidly growing threats to agricultural biodiversity, livelihoods, animal and human health, forestry and biodiversity which result in huge economic losses. They occur in all major taxonomic groups including viruses, fungi, higher plants, ferns, algae mosses, invertebrates, fish, reptiles, amphibians, birds and mammals. According to the International Union for Conservation of Nature and Natural Resources (IUCN) invasive insect pest is one which becomes established in natural or semi-natural ecosystems or habitat, and threatens native biological diversity. These insect pests can multiply in large numbers and cause damage to economically important crop plants. These pests become invasive in introduced area due to the absence of natural enemies and favourable environment parameters. In India, the Directorate of Plant Protection Quarantine and Storage (DPPQ\&S) is responsible for implementation of Destructive Insect and Pest Act (DIPA), 1914 through Plant Quarantine (Regulation of Import into India) Order, 2003 to prevent entry, establishment and spread of exotic plant pests into India to safeguard agriculture, horticulture and forest tree plants. There are about 23 invasive insect pests reported in India. This paper reviews the various biological control options for the invasive pests.
\end{abstract}

\section{Keywords}

Invasive pest, Legal restriction, Management and status, Natural enemy 


\section{Introduction}

Biological control is the reduction in population density of an organism through the use of its natural enemies. For managing invasive species, this approach has been recognized as one of most effective, cost-efficient and providing long-term control. Natural enemies (parasites, predators, herbivores, and pathogens) can reduce the host population; in turn the host abundance also influences the population levels of the natural enemies. Invasive alien species occur in all major taxonomic groups, including viruses, fungi, ferns, algae mosses, higher plants, invertebrates, fish, amphibians, reptiles, birds and mammals. Invasive species are hardy, long lived, voracious, aggressively pervasive, rapid growth, very resilient, generalized diet, ability to move long distances and prolific breeding. They are exotic or nonnative organisms that occur outside their natural adapted habitat and dispersal potential. However, some of the invasive insect pests become invasive when they are introduced deliberately or unintentionally outside their natural habitats into new areas where they express the capability to invade, establish and outcompete native species. National Plant Protection Organizations (NPPO) has curtailed the intentional accidental or introduction of plant pests into newer areas through legal mechanisms. In India, the Directorate of Plant Protection Quarantine and Storage (DPPQ\&S) is responsible for implementation of Destructive Insect and Pest Act (DIPA), 1914 through Plant Quarantine (Regulation of Import into India) Order, 2003 to prevent entry, establishment and spread of exotic plant pests into India to safeguard agriculture, horticulture and forest tree plants. There are steps of invasion by alien organisms can be divided into four steps:

\section{- Introduction of invasive alien pest}

- Establishment

- Spread

- Naturalization.

Introduction of invasive alien pest: Some non-native species are imported intentionally for economic purposes, but many others arrive unintentionally in shipping containers, infesting fruits carried by tourists, or hidden in soil of imported ornamental plants. The introduction of invasives can occur through: Long distance migrations or movements (e.g. the brown planthopper, Nilaparvata lugens in rice), Transportation e.g. Parthenium along with wheat grains in India, Human activities and Aquarium plants e.g. water fern, water lettuce.

Establishment: Once the invaded species has overcome the environmental barriers in the introduced area then it establishes itself and at this stage populations are sufficiently large and the probability of local extinction due to environmental factors becomes negligible.

Spreading: The spreading of a species into areas away from initial sites of introduction requires that the introduced species have also to overcome barriers to dispersal within the new region which can cope with the abiotic environment and biota in the area. 
Naturalization: Naturalization starts when abiotic and biotic barriers to survival rate are surmounted and when various barriers to regular reproduction are overcome. There are about 23 invasive insect pests reported in India (Table 1). The new invasive pest may thrive well in the invaded country due to lack of natural enemies in that area. This paper reviews the various biological control options for the invasive pests.

\section{Natural enemies reported}

A field surveys in Jammu \& Kashmir and Himachal Pradesh reported that 4 species of parasitoids viz. Aphytis proclia Walker, Azotus perspeciosus Girault, Encarsia perniciosi (Tower) and Teleterebratus perversus Compere and Zinna and 4 predator species viz. Chilocorus bijugus Mulsant, Coccinella septempunctata Linnaeus, Pharoscymnus flexibilis Mulsant and Sticholotis marginalis Kapur as effective biocontrol agents of Q. perniciosus in Jammu and Kashmir, while in Himachal Pradesh they found only 1 species of parasitoid i.e Aphytis proclia Walker and 3 species of predators viz. C. bijugus, C. septempunctata and $P$. flexibilis attacking the pest. Many natural enemies were reported from Himachal

Table 1. List of important invasive pests of India.

\begin{tabular}{|c|c|c|c|}
\hline Common name & Scientific name & Year of introduction & References \\
\hline Woolly apple aphid & Eriosoma lanigerum & 1889 & Mishra (1920) \\
\hline San Jose scale & Quadraspidiotus perniciosus & 1921 & Singh (2004) \\
\hline Lantana bug & Orthezia insignis & 1915 & $\begin{array}{l}\text { Muniappan et al. } \\
\text { (1986) }\end{array}$ \\
\hline Cottony cushion scale & Icerya purchase & 1921 & Singh (2004) \\
\hline Potato tuber moth & Phthorimaea operculella & 1906 & Singh (2004) \\
\hline Diamond back moth & Plutella xylostella & 1914 & Fletcher (1914) \\
\hline Pine woolly aphid & Pineus pini & 1970 & Singh (2004) \\
\hline Subabul psyllid & Heteropsylla cubana & 1988 & Jalali and Singh (1989) \\
\hline Serpentine leaf miner & Liriomyza trifolii & 1990 & Singh (2004) \\
\hline Coffee berry borer & Hypothenemus hampei & 1990 & Vega et al. (1999) \\
\hline Spiraling whitefly & Aleurodicus disperses & 1994 & $\begin{array}{l}\text { Palaniswami et al. } \\
\text { (1995) }\end{array}$ \\
\hline Silver leaf whitefly & B. tabaci & 1905 & Singh (2004) \\
\hline Blue gum chalcid & Leptocybe invasa & 2001 & Singh (2004) \\
\hline $\begin{array}{l}\text { The coconut eriophid } \\
\text { mite }\end{array}$ & Aceria gurreronis & 1997 & Singh (2004) \\
\hline Papaya mealy bug & Paracoccus marginatus & 2008 & Jhala et al. (2008) \\
\hline Cotton mealy bug & Phenococcus solenopsis & 2005 & Nagrare (2009) \\
\hline Erythrina gall wasp & Quadrastichus erythrinae & 2005 & Faizal et al. (2006) \\
\hline $\begin{array}{l}\text { South American to- } \\
\text { mato leaf miner }\end{array}$ & Tuta absoluta & 2014 & Sridhar et al. (2014) \\
\hline Fall armyworm & S. frugiperda & 2018 & Shylesha et al. (2018) \\
\hline
\end{tabular}


Pradesh such as Aphytis sp. Nova proclia (Walker), Encarsia perniciosi (Towers) and the Teleterbratus perversus Compere and Zinna. The effective Preator, Chilocorus bijugus Mulsant (Coleoptera : Coccinellidae) is reported by Rawat et al. (1993).

\section{Management in India}

For the suppression of the Q. perniciosus on apples, augmentative and inoculative releases of the two exotic parasitoids, Encarsia perniciosi (Tower) and Aphytis proclia (Walker)/Aphytis diaspidis (Howard) @ 2000/infested tree showed promising results. In Kashmir studies on the biology of E. perniciosi revealed the multiplication rate of parasitoids over 10 times and releases of E. perniciosi and A. proclia showed increase in parasitism from $8.9 \%$ to $64.3 \%$.

\section{Pine woolly aphid (Pineus pini Macquart; Adelgidae: Homoptera)}

Status: Pine woolly aphid, P. pini was first introduced in India in the 1970s. In the Nilgiris hills of South India, the pest has caused severe damage to the Pinus patula plantations. As only the trial plantations had been established, the damage has been restricted to the Pinus patula and further spread of the pest has been contained by discontinuous planting of $P$. patula. This aphid has moved into new areas mostly by movement of infested planting stock.

Biological control: In USA (Hawaii) Pineus aphids have been controlled successfully by the introduction of the natural enemies such as predatory species L. tapiae and L. nigraluna, in Kenya by Exochomus spp., in Zimbabwe by coccinellid beetles and by Exochomus quadripustulatus and Diomus pumilo in Australia (fao.org).

San Jose scale (Quadraspidiotus perniciosus Comstock; Diaspididae: Homoptera)

Status: It has possibly entered the Kashmir valley either in the late 19th or early 20th century. In Himachal Pradesh it was first reported in 1921 in Kullu valley and at Kotgarh (Shimla) in 1924 and then it has spread further to nearly all of the apple growing areas in the country. It is known to have high fecundity and fast multiplication rate especially in warmer areas. Q. perniciosus is a key pest of apple in certain hilly tracts of India.

\section{Lantana bug (Orthezia insignis Browne; Orthezidae: Homoptera)}

In 1915 it was introduced into India, Nilgiri region from Sri Lanka or West Indies. O. insignis native to Neotropical region, probably Guyana and neighbouring countries.

\section{Hyperaspis pantherina Fursch}

Management: O. insignis has a history of successful biological control in Hawaii and several African 
countries, through the introduction between 1908 and 1959 of the predatory South American coccinellid beetle, Hyperaspis pantherina. Successful biological control and protection of indigenous flora from the scale insect has also been achieved by H. pantherina on the island of Saint Helena in the South Atlantic Ocean; the action was successful in saving a field population of an 'Endangered (ER)' endemic gumwood species from extinction.

\section{Cottony cushion scale (Icerya purchasi Maskell; Margarodidae: Homoptera)}

Status: It was accidently introduced into India in 1921. In the Nilgiris and Pulneys there was a serious outbreak of Fluted or cottony cushion scale on citrus and other plants in 1941. The pest is now known to be present throughout country.

Management using bio control agents: I. purchasi populations have been suppressed in numerous countries with Rodolia cardinalis. In India R. cardinalis was introduced in 1929 in Tamil Nadu for control of Icerya purchasi. In Coorg and Bombay provinces in 1946 efforts were made to multiply and distribute some of its natural enemies, particularly the beetle $R$. cardinalis and the moth Euzophera cocdphaga and as a result of which the pest has been nearly eradicated and its spread to other provinces has been checked.

\section{Woolly apple aphid (Eriosoma lanigerum Hausmann; Aphididae: Homoptera)}

Status: Woolly apple aphid, E. lanigerum introduced in India during the $18^{\text {th }}$ century when apple cultivation had begun; but its first available record is from Conoor (South India) where the pest was reported to have almost destroyed every apple orchard. The pest had introduced on the imported apple stocks (Misra, 1920). E. lanigerum is distributed widely in India. It reproduces all year round on apple and crab apple. It is the most serious pest of apple in India, causing damage to root as well as the shoot systems. It imbibes the sap and infested plant parts become distorted badly due to formation of gall resulting into loss of the plant vitality and poor qualitative and quantitative yields. It was first recorded in Conoor during 1889 and in 1909 reported from Kumaun in Hills of Utter Pradesh (now in Uttarakhand) and in 1910 from Shimla. During 1920, it reached a pest status in India.

\section{Natural enemies}

Predators: Lady beetle, lacewing, syrphid fly, Syrphus opinator Osten Sacken, Heringia calcarata Loew, Eupeodes fumipennis Thomson, Eupeodes americanus Wiedemann, Chrysopa nigricornis Burmeister, Coccinella transversoguttata Brown and Hippodamia convergens Guerin-Meneville), A. bipunctata, Harmonia axyridis (Pallas), Coccinella septempunctata L., Chrysoperla plorabunda, Hemerobius spp., damselbugs, Deraeocoris brevis (Uhler) (Hemiptera: Miridae), spiders (Araneae), and earwigs (Dermaptera), Coccinella novemnotata, Chrysopa coloradensis Banks, Deraeocoris brevis. 
Parasitoids: Aphelinus mali Haldeman

Entomopathogens: Beauveria bassiana, Metarhizium anisopliae, Verticillium lecanii, Neozygites fresenii. The effective predators for the management included Coccinella septempunctata, Ballia ancharis, Chilomenes bijugus, Exochomus uropygialis, Coleophora sunzeti.

Management: In India, an attempt to introduce A. mali from England was successful. It was originally released in Shimla and the parsitoid was later found to have colonized successfully in the entire apple growing areas of the country.

\section{Potato tuber moth (Phthorimaea operculella Zeller; Lepidoptera : Gelechiidae)}

Status: P. operculella introduced in India along with the potato seed brought from Italy in 1906. Phthorimaea operculella is now present in almost all the potato-producing states of India and is considered to be one of major pest of the Potato crop in the several states. The tuber damage in the storage has been found to range from 1 to $72.5 \%$ as reported in the endemic states. In Karnataka and Himachal Pradesh, losses upto $100 \%$ in the storage have been reported.

Management: In India, insecticides are commonly used to keep the pest below ETL with bio agents Chelonis blackburni and Copidosoma kochleti, Chrysoperla zastrowi sillemi, Orius albidipennis and Labidura riparia (Chandish et al., 1989).

\section{Diamond back moth (Plutella xylostella Linn.; Plutellidae: Lepidoptera)}

Status: In India, P. xylostella was reported in 1914 (Fletcher, 1914) on the cruciferous vegetables and is now the most devastating pest of the cole crops in the some of the states viz. Punjab, Haryana, Himachal Pradesh, Delhi, Uttar Pradesh, Bihar, Tamil Nadu, Maharashtra and Karnataka. Occurrence of Plutella xylostella outbreak was reported in agro-climatic conditions of Aligarh, western part of Uttar Pradesh, India during September to the first fortnight of October in 2006 on cauliflower.

Management: It was concluded that the larvae and less frequently also the pupae of P. xylostella are sometimes attacked naturally by the pathogens and the two fungi, Erynia blunckii and Zoophthora radicans are predominantly associated with the pest. Other pathogens associated were one other entomophthoraceous fungus, a granulosis virus, one or possibly two nucleopolyhedrosis viruses and Bacillus thuringiensis var kurstaki. In Aligarh Cotesia plutellae was reported to be a dominant larval parasitoid while, Oomyzus sokolowskii parasitized relatively few pupae of Diamond back moth. It was also concluded that in India the dominant parasite is Apanteles plutellae, parasitizing up to $72 \%$ of the $P$. xylostella larvae. The major mortality factor in $1^{\text {st }}$ and $2^{\text {nd }}$ instar larvae is parasitism by A. plutellae, predacious ants, birds, spiders and rainfall. The major mortality factor in pupal stage is parasitism by the eulophid Tetrastichus sokolowskii (Cherian and Basheer, 1938). Cherian and Basheer (1938) observed $59.9 \%$ parasitization by Brachymeria excarinata Gahan and $18.2 \%$ parasitization due to Tetrastichus 
sokolowskii Kurdj.

\section{Spiraling whitefly (Aleurodicus dispersus Russell; Aleyrodidae: Homoptera)}

Status: In India this species was first recorded at Nedumangad (Trivandrum) (Thiruvananthapuram, Kerala) in 1994 in the month of March infesting heavily wild tapioca and wild rubber (Jhala et al., 2008). In December 1994, it was noticed infesting a wide range of the host plants such as guava, mulberry, wild tapioca etc. from Calicut, Kunnamkutam, Trichur, Alwaye, Ernakulam, Sherthalai, Alleppey, Kayamkulam, Ouilon, Attinkal, Trivandrum, Neyyattinkara, Parasala and Kaliakkavilai of Kerala and Marthandam, Thiruvattar, Thuckkalay, Nagercoil and Kanyakumari of Tamil Nadu (David and Regu, 1995). A. dispersus is highly polyphagous pest and has been reported on 253 host plants in country. Further, the dense populations of this pest is known to cause premature leaf drop and further the honeydew produced by them serves as a substratum for growth of sooty mould, leading to abandoned crops.

Management: Predators identified were Nephaspis oculata, Delphastus pusillus and Coccinella septempunctata and Parasitoids identified were Encarsia erimicus and Encarsia formosa. It was reported the occurrence of Encarsia haitiensis Dozier (Hymenoptera: Aphelinidae) in Bangalore, Karnataka and also showed that the per cent parasitism was influenced by the host plant. The per cent parasitism ranged from 0.00 to 38.88 on different host plants being highest on Cassia siamea. Ramani (2000) reported both E. haitiensis and Encarsia Guadeloupe Viggiani (Hymenoptera: Aphelinidae) from Lakshadweep Islands (India). The latter species has since then been introduced into mainland India around Bangalore and has well established and is spreading. The two native predators, Axinoscymnus puttarudiahi Kapur (Coleoptera: Coccinellidae) and Cybocephalus sp. are able to discriminate between the parasitized and healthy larvae and pupae (Ramani, 2000). Both the species of parasitoids and the native predators are maintaining the pest under check now wherever they occur.

\section{Coffee berry borer (Hypothenemus hampei Ferrari; Scolytidae: Coleoptera)}

Status: H. hampei was first reported in India from Gudalur in the Nilgiris of Tamil Nadu. It was introduced accidentally in the country, probably through seeds brought by the refugees from Sri Lanka or through illegally imported seeds of coffee. Over the years it has gradually spread to more areas and is now prevalent in almost all the coffee growing zones in the States of Karnataka, Kerala and Tamil Nadu ( $88 \%$ of the coffee area in India). It has not spread to the Non-traditional areas of Andhra Pradesh and Orissa and the North-Eastern India (12\% of coffee area in India).

Management: Several parasitoids that are recorded, three were introduced into India. They are Prorops nasuta Waterston, Cephalonomia stephanoderis Betrem both from Mexico and Phymastichus coffea Lasalle from Colombia through the efforts of NBAII, Bangalore and the Coffee Board. The isolated fungus Beauveria bassiana (Balsamo) Vuillemin from dead and moribund coffee berry borers and cultured on yeast extract peptone supplemented liquid medium. A suspension of the isolate $(\mathrm{Bb} 2)$ was prepared in 
the sterile water. The laboratory studies were conducted on coffee berry borers by applying conidial suspensions at a dosage rate of $1 \times 10^{6}$ conidia ml-1. Mean insect mortality rates of $69.3,86.9$ and $95.3 \%$ occured at 50, 70 and 90\% RH conditions, respectively. They also conducted field experiments in the coffee plantation area in Kodagu district of Karnataka, and it was observed that under the favourable environmental conditions $\left(27 \pm 29^{\circ} \mathrm{C} ; 82 \pm 91 \% \mathrm{RH} ; 10 \pm 15\right.$ inches rainfall per year), the fungus required only eight days to colonize and kill the target pest. A mean insect mortality level of $61.2 \%$ was obtained after eight days of spraying. A maximum of $75.6 \%$ mortality was recorded after 24 days of spraying. Ten isolates of the entomopathogenic fungus Metarhizium anisopliae in the laboratory for infectivity to the coffee berry borer $H$. hampei. The adult beetles were treated with four spore concentrations $\left(10^{5}\right.$, $10^{6}, 10^{7}$ and $10^{8}$ per $\mathrm{ml}$ ). It was reported that eight isolates caused more than $90 \%$ infection at the highest spore load.

\section{Silver leaf white fly (Bemisia tabaci Bellows; Aleyrodiadae: Homoptera)}

Status: The first record of presence of B. tabaci in India was in 1905 from cotton. Whitefly, B. tabaci is the major sucking pests on cotton in northern and southern India, while the whiteflies are the predominant sucking pests on brinjal in eastern India. Huge populations of whiteflies were recorded during 2015 in Punjab, Haryana and Rajasthan leading to considerable economic losses to the farmers.

Management: A field survey during 2016 and 2017 in different cotton growing districts of Punjab reported the presence of Sixteen species of natural enemies including 7 species of insect predators (Coccinella septempunctata Linneaus, Cheilomenes sexmaculata (Fabricius), Brumoides suturalis (Fabricius), Serangium parcesetosum Sicard, Chrysoperla zastrowi sillemi (Esben-Peterson), Zanchius breviceps (Wagner), Geocoris sp.); 2 species of parasitoids (Encarsia lutea (Masi), Encarsia sophia (Girault \& Dodd)) and 7 species of spiders (Neoscona sp., Argiope sp., Oxyopes sp., Thomisus sp., Runcinia sp., Hyllus sp., Chrysilla sp.). Among these, Chrysoperla was the found to be predominant species. The parasitization by Encarsia spp. on whitefly in different cotton growing areas of Punjab ranged from 1.5 to $9.1 \%$. Srinivasa et al. (1999) reported the occurrence of Encarsia haitiensis Dozier in Bangalore, Karnataka and also showed that the per cent parasitism was influenced by the host plant. The per cent parasitism ranged from 0.00 to 38.88 on different host plants being highest on Cassia siamea Lamk. (Fabaceae). Ramani (2000) reported both E. haitiensis and E. guadeloupe Viggiani from Lakshadweep Islands (India). The latter species has been introduced into mainland India around Bangalore and has well established and is spreading. The two native predators, Axinoscymnus puttarudiahi Kapur (Coleoptera: Coccinellidae) and Cybocephalus sp. are able to discriminate between the parasitized and healthy larvae and pupae (Ramani, 2000). Both the species of parasitoid and the native predators are maintaining the pest under check now wherever they occur.

\section{Serpentine leaf miner (Liriomyza trifolii Burgess; Agromyzidae: Diptera)}

Status: The serpentine leaf miner, Liriomyza trifolii (Burgess) was accidentally introduced into India 
from American sub-continent along with Chrysanthemum cuttings. In India, L. trifolii damage was first reported from castor (Ricinus communis L.) in 1992. Serpentine leaf miner L. trifolii gradually attaining the major pest status in different region of the country and reported to cause $35 \%$ losses in tomato crop. The Serpentine leaf miner, L. trifolii entered India during 1990-1991.

Management: Among the parasitioids Diglyphus begini (Ashmead), D. intermedius (Girault) and Chrysonotomyia punctiventris (Crawford) seems to be promising in exerting practical control of the pest under greenhouse conditions in different parts of Europe. In India, parasitism by the indigenous parasitoids ranges from 0-39 per cent in Bangalore on tomato and cucumber to 49 per cent in Gujarat on castor and Hemiptarsenus varicornis (Girault) is the most predominant one (Kapadia et al., 1997). D. begini was introduced into India from California, USA and field released in the vegetable gardens around Bangalore during 1997 after laboratory tests. Reports indicate that it has not established in the field. 45 species of Chalcidoidea and Braconidae reported on larval and pupal stages of L. trifolii from different parts of world. The parasitism in some areas may be as high as 51-98 per cent (Neuenschwander et al., 1987).

\section{Papaya Mealy bug (Paracoccus marginatus; Pseudococcidae; Hemiptera)}

Status: Paracoccus marginatus was first reported in India in Tamil Nadu in 2008. It assumed the status of a major pest in India in 2009 when it caused severe damage to economically important crops and huge losses to farmers in Coimbatore, Erode, Tirupur and Salem districts of Tamil Nadu. It has a wide host range. In Kerala, during 2010-12 periods, 95 host plants were recorded belonging to 39 plant families. Highest number of host plants of P. marginatus was recorded under the family Euphorbiaceae. Heavy population build up was recorded on 44 host, moderate incidence on 27 plants and on 21 hosts, the infestation severity was low. Spatial distribution studies showed that the variance to mean ratio was the highest on Manihot esculenta Crantz (>100) and lowest on Phyllanthus amarus Schumach \& Thonn. (0.63).

Management: The pest was successfully managed through the intervention of classical biological control wherein Acerophagous papayae was imported from USA. It was observed that biological control of papaya mealybug by releasing parasitoid A. papayae at 100 numbers per hectare proved superior to unreleased field in causing reduction in mealybug population besides recording higher level of parasitoid activity. The mean initial mealy bug population was 48.4 in parasitoid released field and 46.65 in unreleased field. The population of mealy bugs at 15 and 30 Days after Release (DAR) was found to be 28.95 and 16.45 in parasitoid released field respectively. The pre-release mean population of parasitoid was 1.69 in released and 1.45 in unreleased field. At 30 DAR the population of parasitoid count was found to be 5.10 in released and 2.25 in unreleased field.

\section{Subabul psyllid (Heteropsylla cubana Crawford; Psyllidae: Homoptera)}

Status: The tree was almost pest free in India until 1988, when the leucaena psyllid, Heteropsylla cubana, 
appeared in Chengalpetu (Tamil Nadu) and caused severe defoliation and extensive death of young trees. By 1990, it had attacked all the Leucaena plantations in the country.

Management: Natural enemies include the beetles Menochilus sexmaculatus (E), Scymnus gracilis Motschulsky, Harmonia sp. (Coccinelidae), and Paederus fuscipes Curtis (Staphylinidae); the hemipteran Cardiastethus sp. (Anthocoridae); the hymenopteran Ropalidia montana Carl (Vespidae); mantids; reduviids; mirids; syrphids; dragonflies; chrysopids; and spiders. These generalist predators have not provided appreciable control of H. cllbana. The presense of Menochilus sexmaculatus, Scymnus sp. and the exotic Curinus coeruleus, which was released by the National Biological Control Centre, were common on the psyllid population. Other natural enemies recorded were Menochilus sexmaculatus (Fabricius), Scymnus sp., Curinus coeruleus, Pantala flavescens (Fabricius), Ischiodon scutellaris (Fabricius), Stegodyphus socialis Muslont Stegodyphus sarasinomm. A number of native general predators such as Cheilomenes sexmaculatus (Fabricius) (Coleoptera: Coccinellidae) and Pantala flavescens fed on the outbreak populations of the psyllid but they did not exercise the required control. In 1988, the ladybeetle, Curinus coeruleus Mulsant from Mexico it was introduced into India for the biological suppression of H. cubana. The predator has since successfully established in Karnataka, Maharashtra, Andhra Pradesh and Tamil Nadu

\section{Coconut eriophid mite (Aceria gurreronis Keifer; Eriophyidae; Arachnida)}

Status: In India, the mite was reported from many coconut gardens of Kerala during 1997-98 and in Karnataka and Tamil Nadu during 1998-99 and has drawn national attention as a threat to the coconut plantation. Coconut palm, Cocos nucifera Linn. is an important plantation crop grown in India. Among different pests infesting the crop, eriophyid mite, Aceria guerreronis (Keifer) is a serious pest in many coconut growing areas in India. The rapid outbreak of this pest in coconut plantations endangered the copra industry in India, reducing coconut yields and economic profits. This has drawn the attention of farming communities and researchers. To date the most intractable and most damaging pest of coconut fruit is by far the eriophyid mite, A. guerreronis, commonly called "coconut mite". In a survey conducted in 1999 at Kerala, nearly 42 per cent of plants were affected and estimated yield loss was around 22 per cent. The percentage of reduction in nut weight due to mite infestation was estimated as 2.12 per cent.

Management: The fungus Sporothrix fungorum caused epizootic development of A. guerreronis in Karnataka. Two natural enemies are Neoseiulus baraki and Hirsutella thompsonii. Natural occurrence of H. thompsonii contributed to 4.93 per cent. Pathogenicity to coconut eriophyid mite was proved for two species of Hirsutella, H. thompsonii and H. kirchnerii. The other non-specific fungi found to be pathogenic to mites were Acremonium strictum, A. incoloratum, Fusarium lateritium, F. verticillioides, Paecilomyces fumosoroseus and P. lilacinus. The wide spectrum of fungal pathogens associated with A. guerreronis indicates the significant role played by them in the natural suppression of the pest.

\section{Cotton mealy bug (Phenococcus solenopsis Tinsley; Pseudococcidae; Hemiptera)}


Status: In India, it has been recorded as a serious pest on cotton and is widespread throughout cotton-growing states of the country, viz., Punjab, Haryana, Rajasthan, Gujarat, Madhya Pradesh, Maharashtra, Andra Pradesh, Karnataka and Tamil Nadu (Nagrare et al., 2009).Roving survey carried out in Baroda during November 2006 revealed that 25-30\% cotton fields were infested with mealybug and $20-90 \%$ plants were adversely affected causing a reduction of $50 \%$ yield in highly infested fields (Jhala et al., 2008). The earliest $P$. solenopsis infestations in India were recorded in 2005 in Gujarat state Management: Prasad et al. (2011) conducted surveys in cotton fields during 2007-09 in Haryana, Rajasthan and Punjab in the North zone and Madhya Pradesh, Maharashtra and Gujarat in the Central zone indicated that Aenasius bambawalei Hayat (Chalcidodea: Encyrtidae), an indigenous parasitoid, played a key role in reducing the insect pest infestation. The parasitoid was first recorded in Delhi in July 2008 and by 2009 it was found in most of the cotton growing districts of North and Central zones. Its natural parasitization on P. solenopsis could reach more than $90 \%$ at many locations. This is the most successful example of biological control of mealybug. Along with this parasitoid, another parasitoid, Promuscidea unfasciativentris Girault (Chalcidodea: Aphelinidae), was also recorded at most of the locations in smaller proportions.

\section{South American tomato leaf miner (Tuta absoluta Meyrick; Lepidoptera: Gelechiidae)}

Status: In India, T. absoluta was first reported during October, 2014 infesting tomato fields in Pune, Ahmednagar, Dhule, Jalgaon, Nashik and Satara districts of Maharashtra.

Attacks: Nesidiocoris tenuis (Reuter) was found predating on eggs and early instars of T. absoluta under field conditions. Presence of this natural enemy feeding on whitefly in tomato ecosystem in India was earlier reported. Trichogramma achae was also found to attack eggs of Tuta absoluta.

\section{Blue gum chalcid (Gall making insect), Leptocybe invasa (Eulophidae: Hymenoptera)}

Status: In India it was first reported during 2001 from Karnataka. In Karnataka, the gall wasp was reported to be on an attacking spree and damaged 2.5 M eucalypt saplings in the nurseries of two major wood based industries (West Coast Paper Mills and Harihara Polyfibres).

Management: The National Bureau of Agriculture Insect Resources (NBAIR), Bangalore imported Quadrastichus mendeli Kim \& La Salle and Selitrichodes kryceri Kim \& La Salle parasitoids of L. invasa into India. They under quarantine conditions conducted host specificity studies and thereafter recommended its release in the country during 2011-12 (Shylesha, 2012). It is reported, the utilization of native parasitoids viz. Megastigmus dharwadicus Narendran and Vastrad and Aprostocetus gala Walker for biological control of eucalyptus gall wasp, Leptocybe invasa Fisher and LaSalle (Hymenoptera: Eulophidae). Two native parasitoids multiplied in the greenhouse were released in a severely affected eucalyptus plantation spread over an area of 1000 ha. A total of 14,000 heavily parasitized galled seedlings, 1400 M. dharwadicus and 300 A. gala were distributed over a period of six months. The per 
cent parasitization by these native parasitoids was ascertained before distribution of galled seedlings. Though there was a gradual increase in per cent parasitization, the reduction in gall incidence was not evident up to three months. However, drastic reduction in gall incidence and pest emergence accompanied by very high per cent parasitization was evident within eight months. Post release evaluation conducted during June 2011 and May 2012 indicated the successful control of the pest.

\section{Erythrina gall wasp (Quadrastichus erythrinae Kim; Eulophidae; Hymenoptera)}

Status: Quadrastichus erythrinae Kim (Hymenoptera: Eulophidae) In India, it was first recorded from Kerala in 2005. It is a major invasive pest on Erythina spp. in black pepper plantations of Kerala and Karnataka. The Erythina gall wasp was first noticed in 2005 and 2006 and spread to all districts of Kerala and Karnataka and also recorded from Maharashtra. Nearly 60 per cent damage of Erythina plants were observed in Wayanad District of Kerala during 2006. The damage in Erythina plants directly affects production of black pepper in these areas as Erythina plants are used for trailing Black Pepper and Vanilla. Eurytoma erythrinae and Aprostocetus exertus as a new parasitoid of Erythrina gall wasp, Quadrastichus erythrinae.

\section{Fall armyworm (S. frugiperda J. E. Smith)}

Status: In India, the yield losses due to S. frugiperda infestation in maize have been estimated to be varied from 12.4 to 65.7 per cent in Northern Karnataka. Severe damage was noticed in Chikkaballapur, Shivamogga, Hassan, Davanagere and Chitradurga in July-August 2018 (Shylesha et al., 2018).

Attacks: Bioagents from diverse groups including predators, parasitoids and entomopathogens have been recorded against $S$. frugiperda. It is known to be attacked by more than 150 parasitoid and parasite species belonging to 14 families within orders Hymenoptera, Diptera and Nematoda.

\section{Predators}

Several generalist predators are known to feed on different stages of $S$. frugiperda. Some of the important predators are striped earwig, Labidura riparia (Pallas), spined soldier bug, Podisus maculiventris (Say), insidious flower bug, Orius insidiosus (Say) and various ground beetles. Further, vertebrates such as birds, skunks and rodents also have been reported to consume larvae and pupae of S. frugiperda. In India, three species of predators, viz. Harmonia octomaculata (Fabricius), Coccinella transversalis (Fabricius) and Forficula sp. have been recorded from maize fields in Tamil Nadu. In North-East states of India, about 12 predator species have been found associated with S. frugiperda including Eocanthecona furcellata Wolff, Andrallus spinidens (Fabricius), Cosmolestes sp., P. maculiventris, Ropalidia brevita Das and Gupta, Polistes cf. olivaceus (De Geer), Cicindela spp., Rhene flavicomans Simons, Marpissa sp., Oxyopes birmanicus Thorell, Lycosa sp. and indeterminate earwig in maize agroecosystem. 


\section{Conclusion}

Biocontrol has long been considered as an alternative to pesticidal strategies for invasive pest management but its results and level of use globally remain modrate and inconsistently. Biological control is eco-friendly and active means of mitigating insect pest and their effect through use of natural enemies. The objective of biological control is to promote the technology and science. It is a technique of managing pest including insects, fungi, nematodes, mites etc by using other micro-organisms.

\section{Acknowledgments}

The author is thankful to the Department of Entomology, CCSHAU, Hisar for valuable suggestions in formulating this chapter.

\section{References}

Chandish, R.B., Singh, S.P., Jalali, S.K., Kumar, P. (1989). Parasitising efficiency of Chelonus blackburni Cam. and Copidosoma kochleri Blanch singly and in combination against the potato tuber moth. Journal of Biological Control, 3: 4-6.

Cherian, M.C. and Basheer, M. (1938). Tetrastichus sokolowskii Kurdj (Family, Eulophidae) a larval parasite of Plutella maculipenis in South India. Proceedings of the Indian Academy of Science, 9: 87-98.

David, B.V. and Regu, K. (1995). Aleurodicus dispersus Russell (Aleurodidae: Homoptera) a whitefly pest, new to India. Pestology, 19(3):5-7.

Faizal, M.H., Prathapan, K.D., Anith, K.N., Mary, C.A., Lekha, M. and Rini, C.R. (2006). Erythrina gall wasp Quadrastichus erythrinae, yet another invasive pest new to India. Current Science, 90(8): 1061-1062.

Fletcher, T.B. (1914). Some South Indian Insects. Superintendent Government Press, Madras. 565.

Jalali, S.K. and Singh, S.P. (1989). Release and recovery of an exotic coccinellid predator, Curinus coeruleus (Muls.) on subabul psyllid, Heteropsylla cubana Crawf. in India. Journal of Insect Science, 2: 158-159.

Jhala, R.C., Bharpoda, T.M. and Patel, M.G. (2008). Phenacoccus solenopsis Tinsely (Hemiptera: Pseudococcidae), the mealy bug species recorded first time on cotton and its alternate host plants in Gujarat, India. Uttar Pradesh Journal of Zoology, 28(3): 403-406.

Kapadia, M.N. and Butani, P.G. (1997). Record of Serangium parcesetosum Sicard, a predator of sugarcane whitefly in south Saurashtra (Gujarat). Indian Sugar, 47: 503- 504.

Mishra, S.C. (1920). The American blight or wooly apple aphid Erisoma lanigerum (Hausmann). Indian Journal of Agricultural Sciences, 15: 627.

Muniappan, R. and Viraktamath, C.A. (1986). Status of biological control of the weed Lantana camara in India. Tropical Pest Management, 32(40-42): 81-84.

Nagare, V.S., Kranthi, S., Biradar, V.K., Zade, N.N., Sangode, V. and Kakde, G. (2009). Widespread infestation of the exotic mealybug species, Phenacoccus solenopsis (Tinsely) (Hemiptera: Pseudococcidae), on cotton in India. Bulletin of Entomological Research, 99(5): 537-541.

Neuenschwander, P., Murphy, S.T. and Coly, E.V. (1987). Introduction of exotic parasitic wasps for the control of Liriomyza trifolli (Diptera: Agromyzidae) in Senegal. Tropical Pest Management, 33: 290-297.

Palaniswami, M.S., Pillai, K.S., Nair, R.R. and Mohandas, C. (1995). A new cassava pest in India. Cassava Newsletter,19: 6-7. 
Prasad, Y.G., Prabhakar, M., Sreedevi, G. and Thirupathi, M. (2011). Spatio-temporal dynamics of the parasitoid, Aenasius bambawalei Hayat (Hymenoptera: Encrytidae) on mealybug, Phenacoccus solenopsis Tinsely in cotton based cropping systems associated weed flora. Journal of Biological Control, 25(3): 198-202.

Ramani, S. (2000). Fortuitous introduction of an aphelinid parasitoid of the spiraling whitefly, Aleurodicus dispersus (Russell) (Homoptera: Aleyrodidae) into Lakshadweep Islands with notes on host plants and other natural enemies. Journal of Biological Control, 14: 55-60.

Rawat, U.S., Sangal, S.K. and Pawar, A.D. (1993). Seasonal activity of Chilocorus bijugus Mulsant on San Jose scale, Quadraspidiotus perniciousus (Comstock) in apple ecosystem. Journal of Biological Control, 7: 40-43.

Shylesha, A.N., Jalali, S.K., Gupta, A., Varshney, R., Venkatesan, T. and Shetty, P. (2018). Studies on new invasive pest Spodoptera frugiperda (J. E. Smith) (Lepidoptera: Noctuidae) and its natural enemies. Journal of Biological Control, 32(3): 1-7.

Singh, S.P. (2004). Some Success Stories in Classical Biological Control of Agriculture pest in India. APAARI, Bangkok Thailand.

Sridhar, V., Chakravarthy, A.K., Asokan, R.S., Vinesh, K., Rebijith, B. and Vennila, S. (2014). New record of the invasive South American tomato leaf miner, Tuta absoluta (Meyrick) (Lepidoptera: Gelechiidae) in India. Pest Management in Horticulture Ecosystem, 20:148-154.

Srinivasa, M.V., Viraktamath, C.A. and Reddy, C. (1999). A new parasitoid of the spiralling whitefly, Aleurodicus dispersus Russell (Hemiptera: Aleyrodidae) in south India. Pest Management in Horticultural Ecosystem, 5:59-61.

Vega, F.E., Mercadier, G., Damon, A. and Kirk, A. (1999). Natural enemies of the coffee berry borer, Hypothenemus hampei (Ferrari) (Coleoptera:Scolytidae) in Togo and Cote d'Ivoire, and other insects associated with coffee beans. African Entomology, 7(2):243-248.

$* * * * *$

Cite this chapter as: Kumari, S., Singh, B., Dhanda, S. and Dumra, N. (2021). Biological control of invasive pests in India. In: Biological Diversity: Current Status and Conservation Policies, Volume 1, Eds. Kumar., V., Kumar, S., Kamboj, N., Payum, T., Kumar, P. and Kumari, S. pp. 315-328, https://doi.org/10.26832/aesa2021-bdcp-021 